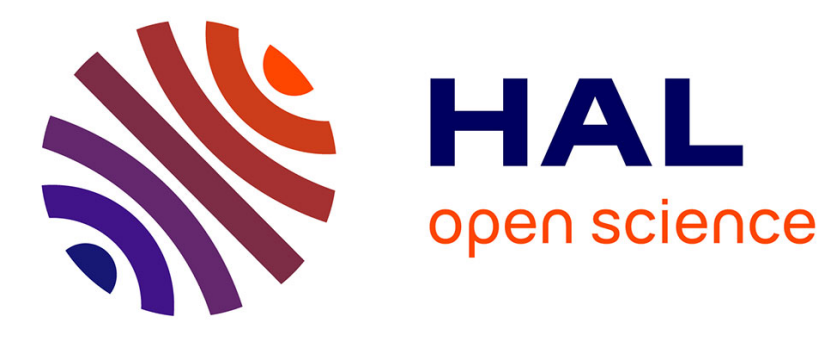

\title{
Perspectives on gender and product design
}

\author{
Susan M. Dray, Daniela K. Busse, Anke Brock, Anicia N. Peters, Shaowen \\ Bardzell, Allison Druin, Margaret M. Burnett, Elizabeth F. Churchill, Gayna \\ Williams, Karen Holtzblatt, et al.
}

\section{- To cite this version:}

Susan M. Dray, Daniela K. Busse, Anke Brock, Anicia N. Peters, Shaowen Bardzell, et al.. Perspectives on gender and product design. ACM CHI Conference on Human Factors in Computing Systems, Apr 2014, Toronto, Canada. pp.53-56, 10.1145/2559206.2559218 . hal-01099496

\section{HAL Id: hal-01099496 https://hal.science/hal-01099496}

Submitted on 2 Nov 2015

HAL is a multi-disciplinary open access archive for the deposit and dissemination of scientific research documents, whether they are published or not. The documents may come from teaching and research institutions in France or abroad, or from public or private research centers.
L'archive ouverte pluridisciplinaire HAL, est destinée au dépôt et à la diffusion de documents scientifiques de niveau recherche, publiés ou non, émanant des établissements d'enseignement et de recherche français ou étrangers, des laboratoires publics ou privés. 


\section{Perspectives on Gender and Product Design}

\author{
Susan M. Dray \\ Dray \& Associates, Inc., USA \\ susan.dray@dray.com \\ Daniela K. Busse \\ Samsung Research, USA \\ daniela.busse@gmail.com
}

\section{Anke M. Brock}

IRIT, Univ. Toulouse, France

anke.brock@irit.fr

\section{Anicia Peters}

Iowa State University, USA

anpeters@iastate.edu

\section{Shaowen Bardzell \\ Indiana University, USA \\ selu@indiana.edu}

\section{Allison Druin}

University of Maryland, USA

allisond@umd.edu

Permission to make digital or hard copies of all or part of this work for personal or classroom use is granted without fee provided that copies are not made or

distributed for profit or commercial advantage and that copies bear this notice and the full citation on the first page. To copy otherwise, or republish, to post on servers

or to redistribute to lists, requires prior specific permission and/or a fee.

CHI 2014 Extended Abstracts, .......

\author{
Margaret Burnett \\ Oregon State University, USA \\ burnett@eecs.oregonstate.edu

\section{Elizabeth F. Churchill} \\ eBay Research Labs, eBay Inc, \\ USA \\ churchill@acm.org
}

\section{Gayna Williams}

If She Can I Can, USA

\section{Karen Holtzblatt}

InContext Design, USA

karen@incontextdesign.com

\section{Dianne Murray}

Interacting with Computers, UK

dianne@city.ac.uk gayna@ifshecanican.com

\begin{abstract}
Interactive technologies have a profound mediating effect on the way we obtain and contribute to knowledge, relate to each other and contribute to society. Often, "gender" is not a factor that is explicitly considered in the design of these technologies. When gender is considered, products are often designed with idealized models of gendered "users"-designed for men, designed for women, designed for boys, designed for girls, or designed for the "average user" who could be male or female. However, the ways in which genderbias or gender-neutrality are constructed in the design process and the resulting effect on the interactive artifacts that are produced is not well understood. This workshop will address what $\mathrm{HCI}$ is currently bringing, and can bring, to the table in addressing this issue.
\end{abstract}

\section{Author Keywords}

Gender; interactive products; technology; HCI; system design; perspectives

\section{ACM Classification Keywords}

H.5.m. Information interfaces and presentation (e.g. HCI): Miscellaneous.

\section{Introduction}

This workshop focuses on the design of interactive systems and products, and with how gender-neutrality or gendered use is constructed and mobilized within the design process. Often, "gender" is not a factor that is explicitly considered in product design; products are 
implicitly considered to be gender "neutral". We are interested in what it means to be gender-neutral and what does it mean to design for the "average user" who could be male or female, boy or girl, (or any other gender identity)? Is it possible to design a genderneutral interactive product? If so, what are the products where design for specific genders is necessary or appropriate? When interactive technologies are intentionally gendered, what are the models of male or female, man or woman, etc. that are tacitly or explicitly constructed and that influence the resultant products? When are products designed with gender in mind, where they are adopted and appropriated by users who do not fit the original user profile? What can we learn from such unexpected uptake?

The impact of neutral, abstracted and/or idealized models of gendered "users"- designed for specific genders explicitly or implicitly, or not - is not very well understood. And it is even less clear how "gender" affects the use of technologies by users of any gender.

Given the impact and potential ramifications of technological products on society, it is imperative that we more deeply understand the tacit and explicit models of the user and especially of gendered practice that underlie design choices. We need to then inclusively accommodate and integrate different perspectives in shaping our modern day technologies.

In recent years, the centrality of gender has become recognized within the $\mathrm{HCI}$ community from multiple perspectives:

- For epistemological frameworks for designing and for understanding the adoption, appropriation and resistance of technologies, with a call for increasing feminist perspectives which highlight issues of agency and power among others. A feminist $\mathrm{HCI}$ manifesto [2] was presented at CHI 2010. And the journal Interacting with Computers featured a special issue on "feminism and $\mathrm{HCI}^{\text {" [1]. }}$

- For reflecting on how designed products embody gender bias, and sit within a broader ecology/milieu of gendered products and structures which also embody biased assumptions around gendered practice, see for e.g., [6][7]

- On the training settings that girls/boys and women/men experience as they develop their careers, see for e.g., [10]

- On career opportunities and career models that are experiences within the technology design and development world including the structure of technology design teams, and broader sociostructural and socio-cultural issues around careerlife balance, see for e.g.,[8][9][10]

- On the design and use of software tools and environments that we work with to produce interactive technologies, see for e.g., [4]

It is clear that gender is on the agenda in $\mathrm{HCI}$ and at $\mathrm{CHI}$. Gender and training/career inequities are on the agenda beyond $\mathrm{HCI}$, of course [3], and there are efforts to broaden the discussion within our community [5].

In this workshop, we wish to take one facet of this conversation further-our particular focus on gender 
bias and notions of gender neutrality in interactive product design.

\section{Workshop GOALS}

This workshop focuses on the bringing to the fore different perspectives of how gender affects technology design, adoption, appropriation, and possibly resistance. We will address what is missing from the discussion, and why. We will consider what, if anything, needs to change in design methods and perspectives.

We will try to elaborate and account for possible gender differences in perceived product value and in actual and perceived ease of use. We will consider whether there are gender-related differences in the creation and experience of delightful engagement with interactive technologies. Examples of issues to be discussed and arenas of potential change are:

- increasing research and understanding of gender impact on technology design and use

- consideration of how to increase representation of nuanced gender perspectives within design processes in the technology sector and within fields related to technology production, including computer science and engineering, and also design, design research, and related fields

- $\quad$ discussing what would constitute gender-agnostic or gender inclusive design/development environments, including consideration of design biases in software tools and in digital and/or physical collaborative design/development settings

- $\quad$ addressing the lack of discussion regarding gender impact in the fields related to technology design, including the field of Human Computer Interaction ( $\mathrm{HCI}$ ) whose very charter is to be "usercentric" and inclusive

- $\quad$ reflecting on the low grant support

for academic research which looks at the representation of gendered perspectives in our current discourse, which in turn leads to a lack of reliable, informative and actionable technology \& gender research

This workshop will address these issues with respect to the tools, technologies, and processes we experience and design, both in industry and academia, and with the aim of producing some actionable steps forward.

We will explore four key areas of interest with the goal of having tentative answers by the end of the day:

- Framing the discussion: From your perspective, is gender an important topic for designers and developers of interactive products? Should we focus our critical and practical energies on Women, on Gender, or on Diversity/Inclusivity? What role(s) should there be for gender politics in the debate?

- Gender-related knowledge and practice in academic, consultancy and corporate HCI and UX as a profession: What is the current status of gender as a topic in the HCI/UX field of work? What are points of view on gender research in $\mathrm{HCI}$ ? What conflicts, if any, exist?

- Gender-sensitive products: Does truly genderneutral design exist? If so, is this a desirable goal? If it is a desirable goal, what has been done toward this goal, what still needs to be addressed? 


\section{- Gender-sensitive design processes and}

practices: Reflecting on creators of software and of interactive products, what are best practices for producing gender-sensitive designs? What are the most effective work practices, work processes and team structures that produce gender-sensitive designs? What challenges exist and what needs to be done to overcome identified challenges in product creation and promotion? Are there requirements gathering methods, design processes and evaluation methods that are specific to different gendered perspectives?

\section{Target Audience}

This workshop is open to all and any members of the HCI community, adjacent communities and people interested in technology design who are concerned with developing a deeper understanding of how tacit and explicit assumptions about gender influence the design, launch, marketing, adoption and appropriation of interactive technologies. As well as engaging in critical discussions about such tacit and explicit influences, hopefully exemplified with case studies, we also invite people who have used novel or inventive approaches in their design methods to raise awareness of gender as it is mobilized in design processes.

\section{Related Works}

[1] Bardzell, S. and Churchill, E.F. IwC Special Issue "Feminism and HCI: New Perspectives". Interacting with Computers 23, 5 (2011), iii-xi.

[2] Bardzell, S. Feminist HCI: taking stock and outlining an agenda for design. Proceedings of the 28th internationa conference on Human factors in computing systems CHI '10, ACM Press (2010), 1301-1310.
[3] Anita Borg Institute, The state of Women and Technology Fields around the World,

anitaborg.org/files/womenhightechworld.pdf. Accessed Oct 32

[4] Burnett, M., Beckwith, L., Wiedenbeck, S., Fleming, S., Cao, J., Park, T., Grigoreanu, V., Rector, K. Gender Pluralism in Problem-Solving Software, Interacting with Computers, 23(5), , 2011, pp. 450-460.

[5] CHI Women Facebook Group.

http://www.facebook.com/groups/222681681100560.

[6] Churchill, E.F. 2010. Sugared puppy-dog tails: gender and design. interactions 17, 2 (March 2010), 52-56.

[7] Dray, S., Peters, A., Brock, A., Peters, A., Bardzell, S., Burnett, M., Churchill, E., Poole, E., and Busse, D.. 2013. Exploring the representation of women perspectives in technologies. In $\mathrm{CHI}$ '13 Extended Abstracts on Human Factors in Computing Systems (CHI EA '13). ACM, New York, NY, USA, 2447-2454.

[8] Dray, S., Peters, A., Brock, A., Peer, A., Druin, A., Gitau, S., Kumar, J., and Murray, D.. 2013. Leveraging the progress of women in the $\mathrm{HCI}$ field to address the diversity chasm. In $\mathrm{CHI}$ ' 13 Extended Abstracts on Human Factors in Computing Systems(CHI EA '13). ACM, New York, NY, USA, 2399-2406.

[9] Kumar, J., Rosenberg, D., Courage, C., et al. Women in UX leadership in business. Proceedings of the 2012 ACM annual conference extended abstracts on Human Factors in Computing Systems Extended Abstracts, ACM Press (2012), 1107-1110.

[10] Peters, A., Dray, S., and Kaye, J. Work life balance in $\mathrm{HCI}$. Proceedings of the 2012 ACM annual conference extended abstracts on Human Factors in Computing Systems Extended Abstracts, ACM Press (2012), 12291232.

[11]STEM Fields And The Gender Gap: Where Are The Women? - Forbes. http://www.forbes.com/sites/work-inprogress/2012/06/20/stem-fields-and-the-gender-gapwhere-are-the-women 